\title{
Comparison of Different Weedicides on Multi-cut Sorghum Sudan Grass Hybrid for Productivity Enhancement and Control of Grassy Weeds
}

\author{
Muhammad Riaz Gondal ${ }^{1,2 *}$, Aqib Riaz ${ }^{4}$, Sultan Ahmad Rizvi², Bushra Zulfiqar², Waqas Naseem², \\ Humara Umar ${ }^{3}$, Ahmad Hussain ${ }^{1}$ and Mazher Iqbal ${ }^{3}$
}

${ }^{1}$ Fodder Research Institute, Sargodha, Pakistan; ${ }^{2}$ Soil and Water Conservation Research Institute, Chakwal, Pakistan; ${ }^{3}$ Barani Agricultural Research Institute, Chakwal, Pakistan; ${ }^{4}$ Hussain Park Military Farm Road, Sargodha, Pakistan.

Abstract | Sorghum is an important fodder crop of Pakistan and weeds infestation reduces its yield and causes harvesting losses upto $20 \%$. Current research aimed to investigate the efficacy of various weedicides to eradicate weedy grasses ( $S$. brevifolius, $D$. aegyptium, $C$. dactylon, S. halepense, B.decufeedipedia.org. and $P$. hysterophorous) in multi-cut sorghum sudan grass hybrid (S.S. Hybrid). Four herbicides namely Clodinafoppropargayl (Clodinafop) @ 0.25 and $0.375 \mathrm{~kg} \mathrm{ha}^{-1}$, Paraquat and Glyphosate @ 1.5 and $2 \mathrm{~L} \mathrm{ha}^{-1}$ and Fenoxaprop-p-ethyl (Puma super) @ 1.0 and $1.5 \mathrm{~L} \mathrm{ha}^{-1}$ were applied on Pak Sudac variety of S. S. Hybrid and compared their control on weedy grasses with a weedy check (no weedicide application) during summer seasons of years 2018 and 2019. It was observed that application of Glyphosate and Paraquat @ $2 \mathrm{~L} \mathrm{ha}^{-1}, 1.5$ $\mathrm{L} \mathrm{ha}^{-1}$ reduced the grassy weeds after first cut of S.S. Hybrid up to $99.6 \%, 87 \%, 64.8 \%$ and $54.3 \%$ respectively. However, somewhat better control i.e., 99.5\%, 98.9\%, and 95.5\%, 94.66\% respectively was obtained during 2019. Clodinafop and Puma super suppressed the grassy weeds only for 10-15 days during 2018 and remained unresponsive during 2019. With the reduction of weeds significant increase in fodder yield was recorded. Thus, Glyphosate and Paraquat at two dose levels i.e., 1.5 and $2.0 \mathrm{~L} \mathrm{ha}^{-1}$ significantly increased the fodder yield to the tune of $189.38,210.99 \mathrm{t} \mathrm{ha}^{-1}$ and $188.08,188.94 \mathrm{t} \mathrm{ha}^{-1}$ respectively. Hence, the investigation lead to the conclusion that Glyphosate and Paraquat were fully effective to control weeds and enhance Fodder yield.

Received | February 26, 2020; Accepted | August 18, 2020; Published | September 11, 2020

*Correspondence| Muhammad Riaz Gondal, Soil and Water Conservation Research Institute, Chakwal, Pakistan; Email: riazgondal1962@ gmail.com

Citation | Gondal, M.R., A. Riaz, S.A. Rizvi, B. Zulfiqar, W. Naseem, H. Umar, A. Hussain and M. Iqbal. 2020. Comparison of different weedicides on multi-cut sorghum Sudan grass hybrid for productivity enhancement and control of grassy weeds. Pakistan Journal of Agricultural Research, 33(3): 673-683.

DOI | http://dx.doi.org/10.17582/journal.pjar/2020/33.3.673.683

Keywords | Control of grassy weeds, Fodder yield, Herbicides, Weed management, Post emergence

\section{Introduction}

$\mathrm{P}$ akistan is a country where agriculture plays a crucial role in the economy. Pakistan's agricultural contributes about 18.19 percent to its Gross Domestic Product (GDP). Moreover, it provides 42.3 percent of the labor force. It is also a major part of foreign exchange and stimulates progress in other sectors as well. (Pakistan Economic Survey, 2018). The focus of agriculture sector in the country is towards its food security. Nevertheless, this sector is facing a number of challenges, such as declining landholdings, degradation of land and water resources, the frequent occurrence of drought and floods, restricted quality seed, deficit in control of insects, pest diseases and weed infestation. Under these situations, farming alone may be a risky enterprise. Hence, livestock sector has attained prime importance to support the 
agriculture sector. However, the success of livestock farming mainly depends on the feed and fodder of high nutritional value, which accounts for 65-70 percent of expenses incurred over the animal feeds (Kumar et al., 2012). Fodder is a cheap source of nutrient supply than concentrated feed and, thus, it calls for putting more emphasis on making the livestock industry economically viable option. In Pakistan, only $12 \%$ of the total cropped area is available for fodder cultivation that is $2.35 \mathrm{~m} \mathrm{ha}^{-1}$ (Chattha et al., 2017).

Pakistan's agriculture is mainly irrigated through one of the world's largest irrigation network that spreads over a wide area of Pakistan. This system is being fed from rainfall and glaciers in the upper areas. As the water, flowing through this system is coming from far off distances so it brings many weed seeds that infest the major crops causing reduced yields. These weeds suppress the main crops by sharing the nutrients and cause diseases as well. The yield of fodder (green and dry) is about 52-54 percent of current demand for livestock. The country is already facing the shortage of fodder to feed its existing livestock. The weeds further reduce the production of fodder yield. This shortage is the main hurdle in the development of livestock sector; furthermore, fodder crops are ignored due to their competition with cash crops. The area under fodder cultivation is reducing at rate of $2 \%$ per decade resulting in shortage of fodder (Sarwar et al., 2002). Comparison of healthy appetite with total feed available from all sources revealed that the livestock is undernourished and animals are 30-50\% of malnutrition (Anonymous, 2000). Low reproductive and production performance of animals are mainly due to the qualitative and quantitative shortage of their feeds (Malede, 2013). The multi-cut property of S.S. hybrid results in more production of fodder as compared to single cut sorghum varieties. A noticeable increase in green fodder yield of S.S. hybrid (199-302\%) and dry matter yield (198$321 \%$ ) compared to single cut sorghum was observed (Hussain et al., 1996). Under an investigation on yield attributes of S.S. hybrid it was noted that 30.2$31.4 \%$ of crude fiber content and $5.5-7.6 \%$ of crude protein content were present in the sorghum; and the highest range was observed in cultivar Hegari (Hussain et al., 1995). Therefore, the development of multi-cut hybrids with better yield, quality and its production technology is essential. Average yield of fresh fodder from S.S. hybrid is very low due to a number of factors including poor quality and quantity of seed, improper planting techniques, deficient nutrition and maximum infestation of weeds (Zulfiqar et al., 2002). Thus, the sufficient supply of high quality fodder can only be assured by minimizing the factors effecting fodder yield for efficient production of livestock.

In Pakistan, weeds instigate massive yield reduction in various field crops (Abbas, 2013). Weeds have been a major cause in reduction of the agriculture production effecting crop growth, yield, and quality. The competition among weeds and crops is measured by weed species, duration of infestation, weed density, their growth pattern and weather conditions. This affects the development and growth of crops, which ultimately results in yield reduction (Freitas et al., 2014; Verma et al., 2017). The yield loss of sorghum due to weeds has been recorded in the range of 15 to $97 \%$ depending on the nature and intensity of the weeds (Thakur et al., 2016). To attain the demand of ever-increasing population under restricted area and assets, we have to feed more livestock (Searchinger et al., 2014). Weed eradication is a salient feature of forage crops production and thus, it must be accounted for particularly when their growth is correlated with higher production cost. Yield and quality of forage crops reduce due to their competition with weeds. Some of the weeds species are toxic as well as inedible for livestock (Green et al., 2003). Weed infestation is one of the factors among those, which adversely influence the forage yield of S.S. hybrid. The loss in quantity and quality of produce is mainly due to weed-crop competition for nutrients, space, light, water along with other growth attributes and weed's allelopathic effect (Gupta, 2004). Production of pearl millet is severely affected by weed infestation because weeds compete to crop plants for assets, ultimately lowers productivity and quality of pearl millet (Bahadur et al., 2015). The adverse effect of weed competition on crop productivity is higher than the collective effect of diseases and insects attack. A weed act as an alternate host and providing shelter for pests and encourages the diseases to spread (Marwat et al., 2005). Thomas, 2005 observed that weed infestation reduced the forage yield up to $90 \%$ and the weed spread is, even more, when the forage crop is at early stage. The weeds that affect growth, productivity as well as the quality of S.S. hybrid forage are T. portulacastrum, C. dactylon, S. brevifolius, D. aegyptium, S. halepense, $B$. decufeedipedia. org. D. muricala (L) mart and $P$. bysterophorous (Thomas, 2005). 
The above facts call for the need for keeping the cultivated fodder, pastures and rangelands free of weeds to maintain the yield of quality fodder for sustainable production and health of livestock. It is necessary to keep the weeds controlled below the threshold level for better crop yield (Moorthy and Das, 1998; Knezevic et al., 2002). To cope with the problem of continuous increase in rate of labor and power, chemical control is the only wise way and weeds density with their dry weight are significantly controlled by chemicals $(2,4 \mathrm{D})$ and manual weeding (Cheema et al., 2006). Moreover, chemical control of weeds is very cost-effective method as compared to manual weeding (Cheema et al., 1988). Research results revealed that recommended doses of post emergence herbicide either alone or combined with DMA-6 efficiently controlled weeds population in wheat crop (Ahmad et al., 1991).

Eradication of weeds is the most important component of getting higher grain production in wheat (Khan et al., 2003). Marwat et al., 2008 declared that chemical eradication of weeds is more effective and economical among other weed controls methods. Limited chemical eradication of weeds in sorghum is due to the reason that Atrazine, Simazine and 2,4-D are the only registered herbicides (Correia and Gomes, 2015). It is essential to investigate the efficacy and residual effects of different herbicides while searching for alternatives of weeds control (Machado et al., 2016). Atrazine is mainly considered to eradicate dicotyledons having low eradication range on grasses. Literature study shows that limited and irrational research work has been carried out on grass control as well as other factors affecting production and quality of S.S. grass hybrid. However, some preliminary investigation on weed control in S.S. hybrid was carried out many years ago by Mohammad et al., 1993 and Hussain et al., 1996. S.S. grass hybrid is sown in March and continuously provides 3-4 cuttings up to November. The first cut is taken up to the end of May, and subsequent cutting is taken at 50 percent flowering with an interval of 45-50 days. Optimal development of grasses occurred during the period of April to August. It is common practice to control broad leaves weeds by the application of weedicides like atrazine in multi cut Sorghum. Grassy weeds are dominant after first cutting of Sorghum Sudan grass hybrid and fodder yield is significantly decreased. To build the gap of livestock production in Pakistan and address the shortage of fodder it is the dire need of the day to control grassy weeds to improve fodder yield and quality on a sustainable basis as well as other factors effecting the fodder production in the country. The current investigation was, therefore, planned to study the influence of commonly available weedicides on forage yield of Sorghum Sudan grass hybrid.

\section{Materials and Methods}

\section{Study site and experimental layout}

This experimental study was carried out at the research area of Fodder Research Institute Sargodha. Pakistan during 2018 and 2019. The study site is located at $32.123^{\circ} \mathrm{N}$ and $72.68^{\circ} \mathrm{E}$ having extreme hot summers and moderate to cool winters. The maximum summer temperature reaches $50{ }^{\circ} \mathrm{C}\left(122^{\circ} \mathrm{F}\right)$ while the winter temperature sometimes drops to freezing point. The trial was laid out in a randomized complete block design (RCBD) under split-plot arrangement with four replicates. The size of plot was kept $6 \mathrm{~m} \times 2.7 \mathrm{~m}$ individually, comprising nine crop rows, $30 \mathrm{~cm}$ apart.

\section{Field preparation and treatment procedure}

This investigation was planned to assess the influence of various after-emergence weedicides on the mortality of weedy grasses as well as the growth of Sorghum Sudan grass hybrid (S.S. hybrid) under irrigated conditions. The field was prepared by applying two ploughing with cultivator followed by one ploughing with rotavator. The recommended doses of NPK @ 57:57:0 $\mathrm{kg} \mathrm{ha}^{-1}$, full dose of $\mathrm{P}$ and half dose of $\mathrm{N}$ were applied at the time of seedbed preparation and the remaining half $\mathrm{N}$ was spread with first irrigation after 25-30 days of planting and $\mathrm{N} @ 57 \mathrm{~kg} \mathrm{ha}^{-1}$ after each cutting. According to the recommendations, seeds of S.S. grass hybrid variety @ $20 \mathrm{~kg} \mathrm{ha}^{-1}$ were sown with hand drill during the first fortnight of March 2018 and 2019. All the production technology was tracked according to recommendations except treatments. Application of herbicide i.e. Atrazine was casted@4.25 L ha ${ }^{-1}$ in all treatments to control the broadleaf weeds after the first irrigation when field was at wattar conditions and the first cut was taken at $50 \%$ flowering after about 90 days of sowing. The treatments were kept as Clodinafop (D1 and D2) @ 0.25 and $0.375 \mathrm{~kg} \mathrm{ha}^{-1}$, Paraquat (D1 and D2) @ 1.5 and $2 \mathrm{~L} \mathrm{ha}^{-1}$, Glyphosate (D1 and D2) @ 1.5 and $2 \mathrm{~L}$ $\mathrm{ha}^{-1}$, Puma super (D1 and D2) @ 1 and $1.5 \mathrm{~L} \mathrm{ha}^{-1}$ and control (weedy check). Source, purity and analytical grades of these herbicides are follow as: 


\begin{tabular}{|c|c|c|c|}
\hline Product name & Source/ active ingredient & Purity level & Analytical grade \\
\hline Atrazine & Syngenta / triazine class & $92-97 \%$ & Standard $69 \mathrm{gm} \mathrm{L}^{-1}$ Solubility $7 \mathrm{mg} / 100 \mathrm{ml}^{-1}$ \\
\hline Clodinafop & Clodinafop proporgyl & $>98 \%$ & Standard $69 \mathrm{gm} \mathrm{L}^{-1}$ \\
\hline Paraquat & Syngenta / Paraquat & $96 \%$ & Standard $620 \mathrm{gm} \mathrm{L}^{-1}$ \\
\hline Glyphosate & MonSento/ N. Glycine N. phosphonomethyl & $99.7 \%$ & $950 \mathrm{gm} / \mathrm{Kg}$ \\
\hline Puma super & Bayer/ Fenoxaprop-p-ethyl & $\geq 97$ & Standard $69 \mathrm{gm} \mathrm{L}^{-1}$ \\
\hline
\end{tabular}

All the herbicides were applied within 2-3 days after harvesting i.e., just before the start of re-sprouting of crop and the response of weeds was observed on application of post-emergence weedicides. Weed population in terms of total weeds (tillers $\mathrm{m}^{-2}$ ) before and after the application of herbicides and after the crop harvesting (i.e., each cut up to end of season) was recorded using a quadrate of $\mathrm{m}^{2}$. Two samples of weed population taken from each treatment were converted into weed mortality percentage after taking their mean. Besides herbicide, various yield parameters of S.S. hybrid viz, number of tillers per $\mathrm{m}^{-2}$, number of leaves tiller ${ }^{-1}$, height of plant $(\mathrm{cm})$, thickness of stem $(\mathrm{cm})$, leaf area $\left(\mathrm{cm}^{2}\right)$, fodder yield $\left(\mathrm{t} \mathrm{ha}^{-1}\right)$ were recorded at 50\% flowering of crop. Then entire plots were harvested and weighed with the help of spring balance (model $A N D S F-30 \mathrm{KA}$ having error $=0.01$ ) to record the fodder yield in $\mathrm{t} \mathrm{ha}^{-1}$.

\section{Statistical analysis}

The data of various yield parameters taken from ten (10) randomly selected plants out of each treatment were analyzed by converting each into the mean value and evaluating. Similarly, two samples on grassy weeds taken out of each treatment averaged to a mean value and analyzed. All the recorded data were statistically analyzed by using Fisher's analysis of variance and least significant difference (LSD test) at 5 percent probability level to compare the means of each treatment (Steel et al., 1997).

\section{Results and Discussion}

From recorded data, it was found that two broadleaf weeds i.e., T. portulacastrum, $D$. muricata $(L)$ mart were observed as major broadleaf weeds while some other species (spp.) of grasses were also found in the trails during both the years. The application of broadleaf herbicide atrazine after 26 days of sowing (after 7 days of first irrigation), @ of $4.5 \mathrm{~L} \mathrm{ha}^{-1}$ to all treatments against broadleaf weeds effectively controlled broadleaf weeds from $95 \%$ to $100 \%$ whereas, other species of grassy weeds were controlled from $40 \%$ to $50 \%$, when they were at 3-4 leaves stage. Other scientists, who observed that the atrazine herbicide effectively controlled broadleaf weeds from $73 \%$ to 98\%, obtained similar findings and poor to moderate efficacy against grassy weeds in corn (Idris et al., 2015; Rai et al., 2018). First cut of S. S. grass hybrid fodder was taken after 90 days of sowing during both the year's when $50 \%$ flowering was achieved. It was found that the fodder yield from all experimental plots was statistically similar. The grassy weed flora (tillers $\mathrm{m}^{-2}$ ) were recorded from each plot, just after harvesting and found significant reduction in weed infestation (54.3\%-99.6\%).

\section{Weed infestation and control}

Observation on weed infestation revealed that total five main grassy weeds emerged in 2018 before the application of weedicides those were $S$. brevifolius, $D$. aegyptium, S. halepense, $C$. dactylon, $P$. hysterephorus and $B$. decufeedipedia. org. Infestation of grassy weeds was recorded by counting number of weed tiller $\mathrm{m}^{-2}$ before and after (55-60 days) of application of weedicides when crop was harvested at 50\% flowering to assess the efficacy of different weedicides for long term control of annual and perennial weeds. In 2018, total 325 tillers $\mathrm{m}^{-2}$ of different grassy weeds were observed in the weedy check while in summer 2019, the most dominant grassy weeds spp. were Aegyptus and $S$. halepense and a few plants of $C$. dactylon were found; and the data on weed infestation showed that a total 459 tillers $\mathrm{m}^{-2}$ of grassy weeds were recorded (Tables 1 and 2). During the daily observation of the experiment after application of herbicide, it was observed that both doses of Paraquat (1.5 and $2 \mathrm{~L} \mathrm{ha}^{-1}$ ) burnt all weeds after 4-6 days while the perennial weeds such as $S$. brevifolius, $C$. dactylon and $P$. hysterephorus again re-sprouted after 20-30 days during 2018. The herbicides Clodinafop and Puma super only suppressed the grass spp. for 1015 days and new grass spp. along with suppressed weedy grasses germinated even in the weedy check. After harvesting of the crop at 50\% flowering similar behavior of grassy weeds was observed under the 
Table 1: Effect of herbicides on grassy weeds (tillers $m^{2}$ ) after first cut of S. S. grass Hybrid.

\begin{tabular}{|c|c|c|c|c|c|c|c|c|c|c|c|c|}
\hline \multirow{2}{*}{$\begin{array}{l}\text { Herbicide } \\
\text { application }\end{array}$} & \multicolumn{5}{|c|}{ Grassy weeds count, 2018} & \multicolumn{4}{|c|}{ Grassy weeds count, 2019} & \multicolumn{3}{|c|}{ Average count, 2018 and 2019} \\
\hline & $\begin{array}{l}\text { Before } \\
\text { spray }\end{array}$ & \multicolumn{2}{|c|}{ After spray } & \multicolumn{2}{|c|}{$\begin{array}{l}\text { Mortality } \\
(\%)\end{array}$} & \multicolumn{2}{|c|}{$\begin{array}{l}\text { Before } \\
\text { spray }\end{array}$} & After spray & $\begin{array}{l}\text { Mortality } \\
(\%)\end{array}$ & $\begin{array}{l}\text { Before } \\
\text { spray }\end{array}$ & After spray & $\begin{array}{l}\text { Mortality } \\
(\%)\end{array}$ \\
\hline Clodinafop & 320 & \multicolumn{2}{|c|}{$292.38 B$} & \multicolumn{2}{|c|}{8.63} & \multicolumn{2}{|c|}{441.25} & $462.0 \mathrm{~A}$ & -4.7 & 380.62 & $371.62 \mathrm{C}$ & 2.36 \\
\hline Paraquat & 308.5 & \multicolumn{2}{|c|}{$125.0 \mathrm{C}$} & \multicolumn{2}{|c|}{59.48} & \multicolumn{2}{|c|}{434.63} & $14.13 \mathrm{~B}$ & 96.74 & 371.69 & $69.56 \mathrm{D}$ & 81.28 \\
\hline Glyphosate & 310.63 & \multicolumn{2}{|l|}{$21.25 \mathrm{D}$} & \multicolumn{2}{|c|}{93.15} & \multicolumn{2}{|c|}{446.88} & 11.25B & 97.48 & 378.43 & $16.25 \mathrm{E}$ & 95.7 \\
\hline Puma super & 311.37 & \multicolumn{2}{|c|}{$332.50 \mathrm{AB}$} & \multicolumn{2}{|c|}{-6.9} & \multicolumn{2}{|c|}{444.38} & $458.0 \mathrm{~A}$ & -3.06 & 377.81 & $395.24 \mathrm{~A}$ & -4.61 \\
\hline control & 325 & \multicolumn{2}{|c|}{$341.25 \mathrm{~A}$} & \multicolumn{2}{|c|}{-5} & \multicolumn{2}{|c|}{459} & 480 & -4.5 & 392 & $410.62 \mathrm{~A}$ & -4.75 \\
\hline LSD & NS & \multicolumn{2}{|c|}{45.781} & & & \multicolumn{2}{|c|}{ NS } & 27.018 & & NS & 19.836 & \\
\hline Dose 1 & 314.65 & $228.00 \mathrm{~A}$ & & \multicolumn{2}{|c|}{27.53} & 449 & & 288.85 & 35.78 & 382.22 & $258.42 \mathrm{~A}$ & 32.38 \\
\hline Dose 2 & 315.56 & $216.95 \mathrm{~B}$ & & 31.2 & & 440 & & 278.85B & 36.68 & 377.99 & $247.88 B$ & 34.42 \\
\hline LSD & NS & 6.8337 & & & & NS & & 8.96 & & NS & 11.101 & \\
\hline $\begin{array}{l}\text { Iable 2: Ed } \\
\text { Hybrid. }\end{array}$ & & & & & & & & & & 2 & & of S.S.g \\
\hline Herbicide & Dose ha ${ }^{-1}$ & Gras & sy we & eds cc & unt, 20 & & Gra & assy weeds co & ount, 2019 & Aver: & e count, 201 & 8 and 2019 \\
\hline application & & $\begin{array}{l}\text { Before } \\
\text { spray }\end{array}$ & $\begin{array}{l}\text { Aft } \\
\text { spra }\end{array}$ & & $\begin{array}{l}\text { Morta } \\
\text { (\%) }\end{array}$ & & $\begin{array}{l}\text { Before } \\
\text { spray }\end{array}$ & $\begin{array}{l}\text { After } \\
\text { spray }\end{array}$ & $\begin{array}{l}\text { Mortality } \\
(\%)\end{array}$ & $\begin{array}{l}\text { Before } \\
\text { spray }\end{array}$ & After spray & $\begin{array}{l}\text { Mortality } \\
\text { (\%) }\end{array}$ \\
\hline Clodinafop & $0.25 \mathrm{~kg}$ & 307.5 & 286 & $25 B$ & 6.91 & & 432.5 & 458 & -5.89 & 370 & 372.13B & -0.5 \\
\hline Clodinafop & $0.375 \mathrm{~kg}$ & 332.5 & 298 & $50 \mathrm{~A}$ & 10.22 & & 450 & 453.75 & -0.83 & 391.25 & 376.12B & 3.81 \\
\hline Paraquat & $1.5 \mathrm{Lit}$ & 312 & 142 & $50 \mathrm{C}$ & 54.32 & & 445 & $23.75 \mathrm{C}$ & 94.66 & 378.5 & $83.12 \mathrm{C}$ & 78.03 \\
\hline Paraquat & $2.0 \mathrm{Lit}$ & 305 & 107 & $50 \mathrm{D}$ & 64.75 & & 424.25 & $4.50 \mathrm{C}$ & 98.94 & 364.88 & $56.0 \mathrm{D}$ & 84.65 \\
\hline Glyphosate & 1.5 Lit & 318.75 & 41.2 & & 87.05 & & 460 & $20.50 \mathrm{C}$ & 95.53 & 388.75 & $30.81 \mathrm{D}$ & 92.02 \\
\hline Glyphosate & 2.0 Lit & 302.5 & 1.25 & & 99.58 & & 433.75 & $2.0 \mathrm{C}$ & 99.53 & 368.13 & $1.63 \mathrm{E}$ & 99.55 \\
\hline Puma super & 1.0 Lit & 310 & 328 & $75 \mathrm{~A}$ & -6.04 & & 453.75 & 462 & -1.8 & 381.88 & 395.37AB & -3.5 \\
\hline Puma super & 1.5 Lit & 312.75 & 336 & $25 \mathrm{~A}$ & -7.5 & & 435 & 454 & 4.36 & 373.75 & $395.13 \mathrm{AB}$ & -5.7 \\
\hline Control & - & 325 & 341 & $25 \mathrm{~A}$ & -5 & & 459 & 480 & -4.5 & 392 & $410.62 \mathrm{~A}$ & -4.6 \\
\hline LSD & - & NS & 47. & & & & NS & 30.508 & & NS & 26.485 & \\
\hline
\end{tabular}

Table 3: Effect of herbicides and their doses on S. S. Hybrid fodder yield attributes (mean of 2018-2019).

$\begin{array}{llllll}\text { Herbicides } & \begin{array}{l}\text { Plant height } \\ (\mathrm{cm})\end{array} & \begin{array}{l}\text { Leaves } \\ \left(\text { Tiller }^{-1}\right)\end{array} & \begin{array}{l}\text { Stem diameter } \\ (\mathrm{cm})\end{array} & \begin{array}{l}\text { Leaf Area } \\ \left(\mathrm{cm}^{2}\right)\end{array} & \begin{array}{l}\text { Tiller } \\ \left(\mathrm{m}^{-2}\right)\end{array} \\ \text { Clodinafop } & 221.63 \mathrm{C} & 11.125 \mathrm{BC} & 1.1913 \mathrm{BC} & 370.18 \mathrm{C} & 42.750 \mathrm{C} \\ \text { Paraquat } & 269.13 \mathrm{~B} & 11.875 \mathrm{AB} & 1.3875 \mathrm{~B} & 447.11 \mathrm{~B} & 48.469 \mathrm{~B} \\ \text { Glyphosate } & 292.63 \mathrm{~A} & 12.50 \mathrm{~A} & 1.8125 \mathrm{~A} & 505.88 \mathrm{~A} & 53.188 \mathrm{~A} \\ \text { Puma super } & 223.13 \mathrm{C} & 10.875 \mathrm{C} & 1.2125 \mathrm{BC} & 370.59 \mathrm{C} & 42.563 \mathrm{C} \\ \text { control } & 209.50 \mathrm{D} & 10.50 \mathrm{C} & 1.0875 \mathrm{C} & 359.23 \mathrm{C} & 40.563 \mathrm{C} \\ \text { LSD } & 5.8944 & 0.811 & 0.2034 & 32.851 & 2.29 \\ \text { Dose } 1 & 239.15 \mathrm{~B} & 11.25 & 1.309 & 405.21 & 44.637 \mathrm{~B} \\ \text { Dose 2 } & 247.25 \mathrm{~A} & 11.5 & 1.3675 & 415.99 & 46.375 \mathrm{~A} \\ \text { LSD } & 5.7575 & \mathrm{NS} & \mathrm{NS} & \mathrm{NS} & 1.0128\end{array}$

treatments of Puma super and weedy check whereas the herbicides Clodinafop showed 2.36\% mortality rate (Table 2). The means data with regard to grassy weeds tillers $\mathrm{m}^{-2}$ of second, third and fourth cut after harvesting the S.S. Hybrid forage revealed that the application of herbicide (glyphosate and paraquat) just after first cut significantly decreased the weed quantity over the control treatment. 
Table 4: Interactive effect of different herbicides and their doses on S. S. Hybrid fodder yield attributes (mean of 20182019).

$\begin{array}{lllllll}\text { Herbicides } & \begin{array}{l}\text { Doses } \\ \mathbf{h a}^{-\mathbf{1}}\end{array} & \begin{array}{l}\text { Plant height } \\ (\mathbf{c m})\end{array} & \begin{array}{l}\text { Leaves } \\ (\text { Tiller })\end{array} & \begin{array}{l}\text { Stem diameter } \\ (\mathbf{c m})\end{array} & \begin{array}{l}\text { Leaf Area } \\ \left(\mathrm{cm}^{2}\right)\end{array} & \begin{array}{l}\text { Tiller } \\ \left(\mathbf{m}^{-2}\right)\end{array} \\ \text { Clodinafop } & 0.25 \mathrm{~kg} & 220.0 \mathrm{DE} & 11.0 \mathrm{CDE} & 1.1825 \mathrm{C} & 369.81 \mathrm{C} & 42.813 \mathrm{C} \\ \text { Clodinafop } & 0.375 & 223.25 \mathrm{D} & 11.25 \mathrm{BCDE} & 1.200 \mathrm{C} & 370.56 \mathrm{C} & 42.688 \mathrm{C} \\ \text { Paraquat } & 1.5 \mathrm{Lit} & 261.25 \mathrm{C} & 11.75 \mathrm{ABCD} & 1.300 \mathrm{BC} & 441.41 \mathrm{~B} & 47.813 \mathrm{~B} \\ \text { Paraquat } & 2.0 \mathrm{Lit} & 277.0 \mathrm{~B} & 12.00 \mathrm{ABC} & 1.4750 \mathrm{~B} & 452.81 \mathrm{~B} & 49.125 \mathrm{~B} \\ \text { Glyphosate } & 1.5 \mathrm{Lit} & 283.25 \mathrm{~B} & 12.25 \mathrm{AB} & 1.7750 \mathrm{~A} & 484.12 \mathrm{AB} & 50.063 \mathrm{~B} \\ \text { Glyphosate } & 2.0 \mathrm{Lit} & 302.0 \mathrm{~A} & 12.750 \mathrm{~A} & 1.850 \mathrm{~A} & 527.63 \mathrm{~A} & 56.313 \mathrm{~A} \\ \text { Puma super } & 1.0 \mathrm{Lit} & 221.75 \mathrm{D} & 10.750 \mathrm{DE} & 1.20 \mathrm{C} & 371.46 \mathrm{C} & 41.938 \mathrm{C} \\ \text { Puma super } & 1.5 \mathrm{Lit} & 224.50 \mathrm{D} & 11.0 \mathrm{CDE} & 1.2250 \mathrm{BC} & 369.73 \mathrm{C} & 43.188 \mathrm{C} \\ \text { Control } & - & 209.5 \mathrm{E} & 10.5 \mathrm{E} & 1.0875 \mathrm{C} & 359.23 \mathrm{C} & 40.563 \mathrm{C} \\ \text { LSD } & - & 10.845 & 1.1448 & 0.2714 & 50.156 & 2.7942\end{array}$

The higher doses of Glyphosate and Paraquat (@ 2 liters $\mathrm{ha}^{-1}$ ) showed significantly higher mortality of weeds as compared to low dose (@1.5 L ha-1) (Table 2). The results revealed that the application of glyphosate @2 L ha ${ }^{-1}$ gave the highest control (mortality percentage up to 99.55) and the glyphosate $@ 1.5 \mathrm{~L} \mathrm{ha}^{-1}$ was found statistically at par with the application of Paraquat @2 L ha ${ }^{-1}$ having weeds mortality percentage of 92.02 and 84.65 , respectively (Table 2). The minimum number $\left(1.63\right.$ weeds $\left.\mathrm{m}^{-2}\right)$ was counted in plot treated by glyphosate @2 L ha ${ }^{-1}$ (Table 2), followed by glyphosate @1.5 L ha-1 and Paraquat@2 liters ha ${ }^{-1}$ which were statistically at par showing 30.81 and 56.0 weeds $\mathrm{m}^{-2}$ respectively. The highest weeds tiller (410.62, and 399.75 tillers $\mathrm{m}^{-2}$ ) were found in the control and Puma super treated plots respectively. Other researchers who found considerably decrease in weed density with the application of weedicides in corn crop reported similar results (Khan et al., 2003, 2012; Hassan et al., 2010). Pre-emergence application of atrazine @1.5 $\mathrm{kg} \mathrm{ha} \mathrm{h}^{-1}$ and post-emergence application of Brembo Trione @120 $\mathrm{g} \mathrm{ha}^{-1}$ (after 25 days of sowing) showed significant decrease in grassy weeds count $\left(8.48 \mathrm{~m}^{-2}\right)$ (Sivamurugan et al., 2017). The findings of current study were also in agreement with that of Ashiq et al., 2007, who reported considerable reduction in grassy weeds with the use of weedicides.

\section{Fodder growth and yield parameters}

Plant height: Plant height data pooled over both the years showed that different herbicides and their doses significantly affected the plant height of S.S. hybrid (Table 3). The maximum plant height (302.0 $\mathrm{cm})$ was recorded in the treatments of glyphosate @ 2
$\mathrm{L} \mathrm{ha}^{-1}$ (i.e., $8 \mathrm{ml} \mathrm{L}^{-1}$ water) with minimum infestation (weed density $=1.63$ weed $\mathrm{m}^{-2}$ ) (Tables 2 and 4). In weedy check, lowest plant height $(209.50 \mathrm{~cm})$ was recorded with highest weed density (410.62 weeds tiller $\mathrm{m}^{-2}$ ) (Tables 1 and 4). Decrease in plant height at higher weeds intensity may be due to more revelry between inter-species for the same assets. These conclusions were in concurrent with that of Hussain et al., 2011 who reported that the height of maize fodder reduced by increased intensity (beyond 6 plant $\mathrm{m}^{-2}$ ) of Xanthium strumarium. Celebi et al., 2010 observed that alfalfa (Medicago sativa) height decreased with increase of weed intensity. Safdar et al., 2015 reported a similar finding that maize height was decreased gradually as increase in Parthenium intensity. The effect of interaction of herbicides (Paraquat and Glyphosate) and their doses (6 and $8 \mathrm{ml} \mathrm{L}^{-1}$ water) had significant on plant height. As the dose of herbicide increased the plant height increased and weed density decreased (Tables 1 and 2). At lower level of herbicides, the average plant height $(239.15 \mathrm{~cm})$ was significantly lower than the higher level of herbicides plant height $(247.25 \mathrm{~cm})$ with weeding density 258.42 and 247.88 weeds tiller $\mathrm{m}^{-2}$ respectively. (Tables 1 and 3 ). The competition of weeds with plants of S.S. hybrid was reduced with the application of herbicide. This statement is justified with investigation of Nawab et al., 1999 and Hassan et al., 2010 who observed that the maize height was relatively high in treatments where herbicides were applied.

Number of tillers $\mathrm{m}^{-2}$ : Data on number of tiller $\mathrm{m}^{-2}$ indicated that different weedicides significantly influenced the number of tillers in S.S. hybrid (Table 
$3)$. From the data pooled over both the years, it is observed that the highest number of tillers $(53.188$ $\mathrm{m}^{-2}$ ) were counted in the treatment where glyphosate applied which was followed by Paraquat herbicide (48.469 tillers $\mathrm{m}^{-2}$ ). All other treatments showed statistically similar results on number of tillers $\mathrm{m}^{-2}$. The minimum number of tillers $\mathrm{m}^{-2}$ was recorded in weedy check (control). It was also found that highest dose averaged over responding herbicides resulted in statistically highest number of tillers $\left(46.375 \mathrm{~m}^{-2}\right)$ as compared to lowest applications of weedicide those resulted in lowest number of tillers $\left(44.637 \mathrm{~m}^{-2}\right)$. The interactive effects of weedicides and their doses have a considerable effect on tillers $\mathrm{m}^{-2}$ (Table 4). The data revealed that the highest number of tillers $(56.313$ $\mathrm{m}^{-2}$ ) were observed in the treatment of glyphosate herbicide@2-liter ha-1 (Table 3). Malik et al., 2009 found that the number of tillers considerably enhanced with the application of Buctril Super against broad leave weeds at recommended doses as compared with other herbicide used in investigation. These findings are in comparison with the results that wheat production increased with the application of weedicides as a result of rise in spike length, fertile tillers, grain per spike and grain weight (Malik et al., 1998; Madafiglio et al., 2006).

Number of Leaves per tiller: Data of leaves tiller ${ }^{-1}$ showed that different herbicides considerably affected number of leaves tiller ${ }^{-1}$ however, non-significant effect was observed among doses. Maximum leaves tiller $^{-1}$ (12.50) were found in the glyphosate treated plot, and a statistically same number of leaves tiller ${ }^{-1}$ were noted from experimental plot treated with Glyphosate and Paraquat (@2.0 and $1.5 \mathrm{~L} \mathrm{ha}^{-1}$ ) (Table 3). The lowest number of leaves tiller-1 (10.50) were counted from the plot without the application of herbicides (weedy check). These investigations can be correlated with the findings of Saleem et al., 2015, who reported that maximum plant height, green leaves (11.72) plant $^{-1}$ and stem thickness of maize was achieved from those treatments where $2160 \mathrm{~g}$ $\mathrm{ha}^{-1}$ metalachlor + pendimethalin was sprayed. Malik et al. (2006) observed that a maximum production was achieved from weeds free treatments as more leaf area, leaves plant ${ }^{-1}$, the height of plant, per plant weight lead to increase productivity.

Stem diameter: Different herbicides significantly influenced the stem diameter of S. S. hybrid plants and their doses have a non-significant impact. The highest stem diameter $(1.8125 \mathrm{~cm})$ was calculated from the experimental plots where herbicide glyphosate was spayed which was followed by the experiment unit where Paraquat herbicide applied $(1.3875 \mathrm{~cm})$. The lowest stem diameter $(1.0875 \mathrm{~cm})$ was recorded from the control where no herbicide was applied (Table 3). Data showed the stem diameter decreased as grassy weed intensity increased (Tables 1 and 3). Data on stem diameter averaged over both the years showed that S.S. hybrid plants obtained highest stem diameter $(1.85 \mathrm{~cm})$ in the experimental unit where minimum weed density ( 1.63 weeds tiller $\mathrm{m}^{-2}$ ) was observed and minimum stem diameter $(1.0875 \mathrm{~cm})$ was observed at highest weed intensity (410.62 tillers $\mathrm{m}^{-2}$ ) (Tables 1 and 3$)$. These findings are in concurrent with the conclusions of Asif et al., 2017 and Gholami et al., 2013 who observed that stem diameter reduced in un weeding treatment as compare to other weeding treatments, which shows minimum weed intensity.

Table 5: Effect of different herbicides on fodder yield ( $t$ ha-1) after first cut of S.S. Hybrid.

\begin{tabular}{llll} 
Herbicides & \multicolumn{3}{l}{ S. S. Hybrid Fodder Yield, t ha } \\
& 2018 & 2019 & mean \\
Clodinafop & $147.18 \mathrm{C}$ & $178.03 \mathrm{~B}$ & $162.59 \mathrm{C}$ \\
Paraquat & $171.55 \mathrm{~B}$ & $205.48 \mathrm{~A}$ & $188.52 \mathrm{~B}$ \\
Glyphosate & $198.30 \mathrm{~A}$ & $202.08 \mathrm{~A}$ & $200.19 \mathrm{~A}$ \\
Puma super & $148.93 \mathrm{C}$ & $171.37 \mathrm{BC}$ & $160.11 \mathrm{C}$ \\
control & $137.69 \mathrm{D}$ & $168.81 \mathrm{C}$ & $153.22 \mathrm{D}$ \\
LSD & 5.417 & 5.54 & 5.47 \\
Dose 1 & $158.06 \mathrm{~B}$ & 182.62 & $170.33 \mathrm{~B}$ \\
Dose 2 & $163.40 \mathrm{~A}$ & 187.70 & $175.52 \mathrm{~A}$ \\
LSD & 1.38 & $\mathrm{NS}$ & 2.75
\end{tabular}

The values having different letters in the same column are significantly different $(P \leq 0.05)$.

Leaf area: The influence of different herbicides on leaf area $\left(\mathrm{cm}^{2}\right)$ of S.S. hybrid indicated a significant difference in leaf area and their doses have a nonsignificant effect (Table 3). The treatments where glyphosate herbicide was applied produced the highest leaf area $\left(505.88 \mathrm{~cm}^{2}\right)$ which was followed by Paraquat applied treatment producing lowest leaf area (447.11 $\mathrm{cm}^{2}$ ) whereas the weed density 16.25 and 69.56 tillers $\mathrm{m}^{-2}$ respectively were found (Table 1 ). The leaf area $\left(\mathrm{cm}^{2}\right)$ increased as weed density decreased. Finally, S.S. hybrid plant showed the lowest leaf area of $359.23 \mathrm{~cm}^{2}$ when weeds density was 410.62 tillers $\mathrm{m}^{-2}$ and highest leaf area $527.63 \mathrm{~cm}^{2}$ when weeds density was 1.63 tiller $\mathrm{m}^{-2}$ (Table 4). These investigations are 
correlated with the results of Rezvani et al., 2012, who noted a reduction in soybean leaf area, due to weedy condition and unweedy condition of the crop during the growing season have no considerable negative effect on area of leaf. (Sarabi et al., 2013) also examined, intensity of lamb's quarters $(0,4,8,12$, 16 and 20 plants $\mathrm{m}^{-2}$ ) considerably decreased maize leaf area index, as well as high intensity (16 and 20 plants $\mathrm{m}^{-2}$ ), resulted in the highest reduction in index of leaf area.

Table 6: Interactive effect of different herbicides and their doses on S.S. Hybrid fodder yield after first cut $\left(t \mathrm{~h} \mathrm{a}^{-1}\right)$.

\begin{tabular}{lllll} 
Herbicides & Doses & \multicolumn{4}{l}{ S. S. Hybrid Fodder Yield, tha } \\
& ha $^{-1}$ & 2018 & 2019 & mean \\
Clodinafop & $0.25 \mathrm{~kg}$ & $146.45 \mathrm{D}$ & $178.30 \mathrm{C}$ & $162.38 \mathrm{C}$ \\
Clodinafop & 0.375 & $147.91 \mathrm{D}$ & $177.77 \mathrm{C}$ & $162.8 \mathrm{C}$ \\
Paraquat & $1.5 \mathrm{Lit}$ & $170.43 \mathrm{C}$ & $207.45 \mathrm{~A}$ & $188.94 \mathrm{~B}$ \\
Paraquat & $2.0 \mathrm{Lit}$ & $172.68 \mathrm{C}$ & $203.51 \mathrm{AB}$ & $188.09 \mathrm{~B}$ \\
Glyphosate & $1.5 \mathrm{Lit}$ & $187.18 \mathrm{~B}$ & $191.59 \mathrm{~B}$ & $189.38 \mathrm{~B}$ \\
Glyphosate & $2.0 \mathrm{Lit}$ & $209.42 \mathrm{~A}$ & $212.57 \mathrm{~A}$ & $210.99 \mathrm{~A}$ \\
Puma super & $1.0 \mathrm{Lit}$ & $148.54 \mathrm{D}$ & $166.90 \mathrm{C}$ & $157.72 \mathrm{c} \mathrm{D}$ \\
Puma super & $1.5 \mathrm{Lit}$ & $149.33 \mathrm{D}$ & $175.84 \mathrm{C}$ & $162.51 \mathrm{C}$ \\
Control & - & $137.69 \mathrm{E}$ & $168.81 \mathrm{C}$ & $153.22 \mathrm{D}$ \\
LSD & - & 5.84 & 12.67 & 6.98
\end{tabular}

The values having different letters in the same column are significantly different $(P \leq 0.05)$

Fresh forage yield $\left(\mathrm{tha}^{-1}\right)$ : Data on fodder production revealed that non-significant results were observed at first cut of fresh forage before the application of herbicides when all treatments of the experiment were treated equally. Fodder yield of second cut, after the application of herbicide showed decreasing trend in forage yield at high grassy weeds density during both years 2018 and 2019 (Table 5). Highest fresh fodder yield of 198.30 and $202.08 \mathrm{tha}^{-1}$ were recorded when grassy weeds density (21.25 and $\left.11.25 \mathrm{~m}^{-2}\right)$ was observed during both years 2018 and 2019 respectively (Table 1). As grassy weed density $\mathrm{m}^{-2}$ enhanced, the fresh fodder yield was reduced and reached the minimum yield 137.69 and $168.81 \mathrm{t} \mathrm{ha}^{-1}$ in weedy check (control) during both the years (2018 and 2019) respectively. Fresh forage yield was maximum in the second year (2019) as compared to first year (2018). These differences might be due to variations in status of soil, species of weeds and climatic situation. Reduction in forage production with enhancing grassy weeds density may be attributed to reduce in growth attributes like plant height, leaves per tiller, stem diameter, leaf area and tillers $\mathrm{m}^{-2}$. The findings are in line with the results of Celebi et al. (2010), who noted that fresh forage production of alfalfa (Medicago sativa) was lowest where the maximum intensity of weeds was found and production was the maximum where the lowest density of weeds was found for competition with alfalfa. Massinga et al. (2004) also revealed a notable reduction in maize forage production with increased density of weed. Among herbicide treatments, higher fresh forage yield $\left(200.19 \mathrm{t} \mathrm{ha}^{-1}\right)$ an average of both years was achieved from the plots where glyphosate herbicide was applied (Table 5). Statistically increase in yield component and green fodder yield of S.S. hybrid was attained by applying higher dose of glyphosate @ $2 \mathrm{~L} \mathrm{ha}^{-1}$ than other herbicides and weedy check (control) treatments. These findings are in agreement with the findings of Orson et al. (1998) and Malik et al. (2006); who reported that a maximum production of S.S. hybrid forage was achieved from weed-free treatments due to maximum leaf area, leaf per plant, plant height, fresh plant weight. Under interaction of herbicides glyphosate and its doses $2 \mathrm{~L} \mathrm{ha}^{-1}$ produced maximum green forage production $\left(210.99 \mathrm{t} \mathrm{ha}^{-1}\right)$ the average of both years. While the lowest fodder yield $\left(153.2 \mathrm{tha}^{-1}\right)$ was observed in the control treatment (Table 6). Maximum green fodder yield in treatments where adequate as well as timely weed control has resulted in decrease weed density and consequently fewer weed crop competition for nutrition, light, water and space. The results of current study are in concurrent with findings of Sharma and Jain, 2003 and Carson, 2008, who found that optimum weed management, enhanced the number of seeds per head.

\section{Conclusion and Recommendation}

From the analysis of data and subsequent results it was concluded that the application of atrazine herbicide $@ 4.5 \mathrm{~L} \mathrm{ha}^{-1}$ after seven days of first irrigation (3237 days after sowing) showed maximum control over broad leaf weeds control. The application of glyphosate@2 L ha ${ }^{-1}$ was quite efficient and have highest control over grassy weeds ( $S$. brevifolius, $D$. aegyptium, $C$. dactylon, $S$. halepense, $B$. decufeedipedia. org. and P. hysterophorous) in S.S hybrid after first cut as compared to other herbicides tested under the current study. Paraquat herbicide @ $2 \mathrm{~L} \mathrm{ha}^{-1}$ after first cut before re-sprouting of plants effectively controlled the seasonal grasses (annual grasses) in S. S. hybrid fodder crop. It was also found that the treatment 
with glyphosate produced highest fodder yield in S.S. hybrid when both the perennial and seasonal grasses were present, whereas Paraquat yielded good quality and higher production of S.S. hybrid fodder when only annual or seasonal grasses were found during both scarcity periods (May-June and October-November).

Therefore, it is suggested that grassy weeds can be controlled with the application of glyphosate herbicide (@2 L ha ${ }^{-1}$ ) just after first cut before re-sprouting of plants and broadleaf weeds with the application of atrazine herbicide (@4.5 L ha $\left.{ }^{-1}\right)$ after seven days of first irrigation (32-37 days after sowing). It is also proposed to apply Paraquat herbicide @ $2 \mathrm{~L} \mathrm{ha}^{-1}$ only if annual grasses are present in S.S. hybrid fodder. Further, it is recommended that the herbicides tested under the current study may be tested under various climatic conditions of sorghum growing areas having diverse soil types and be investigated their residual effect on quality of fodder after $1^{\text {st }}$ cut instead of the application of herbicide only pre and post-emergence.

\section{Author's Contributions}

Muhammad Riaz Gondal: Conceptualizing, Planning and executed the study along with data collection

Aqib Riaz: Collection, recording, arranging the data with preliminary analysis.

Sultan Ahmad Rizvi: Reviewing the draft, evaluating the results, final refinement the manuscript.

Bushra Zulfiqar: Literature review, drafting the manuscript and typing the draft of manuscript.

Waqas Naseem: Analyzing the data, preparing and setting of tables, reviewing the literature.

Humara Umar: Assisting in writing the abstract and introduction, arranging the data tables.

Ahmad Hussain: Technical input for overall management and correction of article.

All Authors have read the manuscript and approved for publication.

Mazher Iqbal: Overall final review and preparation of galley proof.

\section{Conflict of interest}

The authors have declared no conflict of interest.

\section{References}

Abbas, M.A.,2013. General agriculture ( $7^{\text {th }}$ edition) Pakistan: Emporium publishers Lahore.
Ahmad, S., Z.A. Cheema, R.M. Iqbal and F.M. Kundi. 1991. Comparative study of different weedicides for the control of broadleaved weeds in wheat. Sarhad J. Agric., 7(1): 1-9.

Anonymous, 2000. Fodder production in Pakistan. Pakistan agricultural research council,Islamabad and food and agricultural organization. Islamabad. pp. 9.

Ashiq, M., N. Muhammad and N. Ahmad. 2007. Comparative efficacy of different herbicides against broadleaf weeds in wheat. Pak. J. Weed Sci. Res., 13(3-4): 149-156.

Asif, M., M. Ayub, A. Tanveer and J. Akhtar. 2017. Estimating yield losses and economic threshold level of Parthenium hysterophorus in forage sorghum. Planta daninha, pp. 35. https://doi. org/10.1590/s0100-83582017350100038

Bahadur, S., S.K. Verma, S.K. Prasad, A.J. Madane, S.P. Maurya, Gaurav, V.K. Verma and S.K. Sihag. 2015. Eco-friendly weed management for sustainable crop production: Review.J. Crop Weed. 11(1): 181-189.

Carson, A.G., 2008. Improving weed management in the draft animal-based production of early pearl millet in the Gambia. Trop. Pest Manage., 33: 359-363. https://doi. org/10.1080/09670878709371183

Celebi, S.Z., K. Sahar, L. Kaya and R.Y. Ozkan. 2010. Effects of the weed density on grass yield of Alfalfa (Medicago sativa L.) in different row spacing applications. Afr. Biotech., 9(41): 68676872.

Chattha, M.U., A. Iqbal, M.U. Hassan, M.B. Chattha, W. Ishaque, M. Usman, S. Khan, M.T. Fayyaz and M.A. Ullah. 2017. Forage yield and quality of sweet sorghum as influenced by sowing methods and harvesting times. J. Basic Appl. Sci., 13: 301-306. https://doi. org/10.6000/1927-5129.2017.13.49

Cheema, M.S., M. Akhtar and M.S. Iqbal. 2006. Performance of different herbicides in wheat under irrigated conditions of southern Punjab, Pakistan. Pak. J.Weed Sci. Res., 12(1-2): 53-59.

Cheema, M.S., M. Afzal and M.S. Ahmad. 1988. Economics of weed control in wheat. Pak. J. Agric. Res., 9(1): 32-36.

Correia, N.M. and L.J.P.Gomes.2015. Selectivity of saflufenacil for sweet sorghum and potential use of Na-Bentazon as a Safener. Planta Daninha. 33(2): 267-274. https://doi.org/10.1590/010083582015000200012 
Freitas, R.S., A.C.S. Hirata, C.J.B. Albuquerque and W.L.B. Borges. 2014. Integrated weed management in sorghum. Inf. Agropecuario., 35(278): 112-119.

Gholami, S., M.M. Moeini, E. Zand and G. Noormohammadi. 2013. Non-chemical management of weeds effects on forage sorghum production. Int. J. Adv. Biol. Biomed. Res., 1(6): 614-623.

Green, J.D. and J.R. Martin. 2003. Weed control of alfalfa and other forage legume crops. University of Kentucky, US. Coop. Ext. Ser., AGR-148.

Gupta, O.P., 2004. Modern weed management (2nd edition). Agrobios Jodhpur, India. pp. 1823.

Hassan, G., S. Tanveer, N.U. Khan and M. Munir. 2010. Integrating cultivars with reduced herbicides rates for weed management in maize. Pak. J. Bot., 42(3): 1923-1929.

Hussain, A., D. Mohammad, S. Riaz and M.B. Bhatti. 1995. Forage yield potential and quality differences among various sorghum genotypes under rainfed conditions. Sarhad J. Agric. 11(3): 291-295.

Hussain, A., M.U. Mufti, S. Khan and M.B. Bhatti and M.B. 1996. Hybrid seed and fodder production in sorghum. Fodder production in Pakistan. Proc. Natl. Conf. Improv. Prod. Util. Fodder Crops Pak., pp. 150-165.

Hussain, Z., K.B. Marwat and J. Cardina. 2011. Common cocklebur competition in forage maize. Weed Technol., 25(1): 151-158. https:// doi.org/10.1614/WT-D-10-00092.1

Idris, K.I., D.A. Dawoud and H.A. Mubarak. 2015. Herbicidal Efficacy of atrazine for Weed Control in Maize (Zea mays L.). SUST J. Agric. Vet. Sci., 16(2): 37-43.

Khan, M.A., K.B. Marawat, N. Khan and I.A. Khan. 2003. Efficacy of different herbicides on the yield and yield components of maize. Asian J. Plant Sci., 3(2):300-304.

Khan, N.W., N. Khanand and I.A. Khan. 2012. Integration of nitrogen fertilizer and herbicides for efficient weed management in maize ( $\mathrm{Zea}$ mays) crop. Sarhad J Agric. 28(3): 457-463.

Knezevic, S.Z., S.P. Evans. E.E. Blankenship. R.C.V. Acker and J.L. Lindquist. 2002. Critical period for weed control: the concept and data analysis. Weed Sci., 50(6): 773-786. https://doi. org/10.1614/0043-1745(2002)050[0773:CPF WCT]2.0.CO;2
Kumar, S., R.K. Agrawal, A.K. Dixit, A.K. Rai, J.B.

Singh and S.K. Rai. 2012. Forage production technology for arable lands. Indian Grassland and Fodder Research Institute, Jhansi-284003. p. 1.

Machado, F.G., A. Jakelaitis, E.A. Gheno, R.S. Oliveira, F.A. Rios, L.H.M. Franchini and M.S. Lima. 2016. Performance de herbicides para o controle de plants danihas no sorgo. Rev. Bras. Herbic., 15(3): 281-289. https://doi. org/10.7824/rbh.v15i3.476

Madafiglio, G.P., R.W. Medd, P.S. Cornish and R. Van de Ven. 2006. Seed production of Raphanus raphanistrum following herbicide application during reproduction and effects on wheat yield. Weed Res., 46(1): 50-60. https:// doi.org/10.1111/j.1365-3180.2006.00479.x

Malede, B., 2013. Role of seeding rates and cutting stages on yield and quality of forage intercropping in the case of north Gondar. Ethiopia, LAP, LAMBERT Acad. Publ., German. ISBN 978-3-659-25690-5-1.

Malik, A.U., I. Hussain, M. Ahmad, M.A. Haji and M. Ali. 2009. Demonstration and evaluation of effect of weedicides on broad leaved weeds on wheat yield. J. Anim. Plant Sci. 19(4): 193-196.

Malik, M.A., F. Zahoor. S.H. Abbas and M. Ansar. 2006. Comparative study of different herbicides for control of weeds in rainfed maize (Zea mays L.). WSSP Absts. Weed Sci. Soc. Pak., pp. 62.

Malik, R.K., A. Yadav, S. Singh and Y.P. Malik. 1998. Development of resistance to herbicides in P. minor and mapping of variations in weed flora. Proc. Int. Conf. Karnel India. pp. 291-296.

Marwat, K.B., Z. Hussain, M. Saeed, B. Gul and S. Noor. 2005. Chemical weed management in wheat at higher altitudes. Pak. J. Weed Sci. Res., 11(3-4): 102-107.

Marwat, K.B., M. Saeed, Z. Hussain, B. Gul and H. Rashid. 2008. Study of various herbicides for weed control in wheat under irrigated conditions. Pak. J. Weed. Sci. Res., 14(2): 1-8.

Massinga, R.A., R.S. Currie and T.P.Trooien. 2004. Water use and light interception under Palmer amaranth L. and maize fodder competition. Weed Sci., 51(4): 523-531. https://doi. org/10.1614/0043-1745(2003)051[0523:WU ALIU]2.0.CO;2

Mohammad, D., P.B. Cox, G.L. Posler, M.B. Kirkham, A. Hussain and S. Khan. 1993. Genotype $\mathrm{X}$ environment interaction and its 
implications in sorghum (Sorghum bicolor) breeding programme. Ind.J. Agric. Sci. 63: 153156.

Moorthy, B.T.S and T.K. Das. 1998. Threshold level of weed umbrella sedge (Cyprus iria) in upland rice (Oryza sativa) under rainfed direct-seeded condition. Ind. J. Agric. Sci., 68(1): 7-8.

Nawab, K., M. Hatam, B.A. Khan, K. Rasul and M. Mansoor. 1999. Study of some morphological characters in maize as affected by time of weeding and plant spacing. Sarhad J. Agric., 15(1): 21-24.

Orson, J.H., A.M. Blair and J.C. Caseley. 1998. Integration of row widths and chemical and mechanical weed control in winter wheat. HGCA-Project Report. At Morley Res. Centre, 161: (CAB. Absts., 2000).

Pakistan Agriculture Economic Survey, 2017-18. 2018 Economic advisers wing, Finance division, Government of Pakistan, Islamabad.

Rai, A., D. Mahata, E. Lepcha, K. Nandi and P.K. Mukherjee. 2018. A Review on Management of Weeds in Maize (Zea mays L.). Int. J. Curr. Microbiol. Appl. Sci. 7(8): 2906-2922. https:// doi.org/10.20546/ijcmas.2018.708.308

Rezvani, M., M. Ahangari and F. Zaefarian. 2012. Effect of cultivars and weeding regimes on soybean yields. Int. J. Agric. Biosys. Eng., 6(9): 714-716.

Safdar, M.E., A. Tanveer, A. Khaliq and M.A. Riaz. 2015. Yield losses in maize (Zea mays) infested with parthenium weed (Parthenium hysterophorus L.). Crop Prot., 70: 77-82. https:// doi.org/10.1016/j.cropro.2015.01.010

Saleem,M.T.,A. Tanveer and T.Abbas. 2015. Weed control in forage maize with pre-emergence herbicides. Herbologia, 15(2): 69-77. https:// doi.org/10.5644/Herb.15.2.06

Sarabi, V., M.N. Mahallati, A. Nezami and M.H.R. Mohassel. 2013. Effects of common lambsquarters (Chenopodium album L.) Emergence time and density on growth and competition of maize (Zea mays L.). Aust. J.
Crop Sci., 7(5): 532.

Sarwar H, J.S. Mishra and A. Kumar. 2002. Effect of planting geometry and forage legumeintercropping system on the yield and quality of forage sorghum (Sorghum bicolor L.). M.Sc. (Hons) Agric. Thesis, Dept. Agron. Univ. Agric. Faisalabad.

Searchinger, T., C. Hanson, J. Ranganathan, B. Lipinski, R. Waite, R. Winter bottom, A. Deinshaw, R. Heimlich, M.C. boval, P. Chemineau and P. Dumas. 2014. Creating a sustainable food future. A menu of solutions to sustainably feed more than 9 billion people by 2050. World resources report 2013-14: Interim findings. World Resources Institute.

Sharma, O.L. and N.K. Jain. 2003. Integrated weed management in pearl millet (Pennisetum glaucum). Ind. J. Weed Sci., 35(2): 134-135.

Sivamurugan, A.P., R. Ravikesavan, A. Yuvaraja, A.K. Singh and S.L. Jat. 2017. Weed 494 management in maize with new herbicides. Chem. Sci. Rev. Lett., 6(22): 1054-1058.

Steel, R.G.D., J.H. Torrie and D. Dickey. 1997. Principles and procedures of statistics: a biometrical approach ( $3^{\text {rd }}$ edition). McGraw Hill Book Co. Inc. New York. pp. 172-177.

Thakur, N.S., B.B. Kushwaha, O.P. Girothia, N.K. Sinha and J.S.Mishra. 2016. Effect of integrated weed management on growth and yields of rainy season sorghum. Indian J. Agron., 61(2): 217- 222.

Thomas, C.G., 2005. Forage crop production in tropics ( $2^{\text {nd }}$ edition). New Dehli Kalyani.

Verma, B.R., H.M. Virdia and D. Kumar. 2017. Effect of integrated weed management on yield, quality and economics of summer sorghum (Sorghum bicolor L.). Int. J. Curr. Microbiol. Appl. Sci., 6(8): 1630-1636. https://doi. org/10.20546/ijcmas.2017.608.196

Zulfiqar,A.M. and M.Asim.2002. Fodder yield and quality evaluation of the sorghum $M$ varieties. J. Agron., 1: 60-63. https://doi.org/10.3923/ ja.2002.60.63 